Article

\title{
Thermoplastic PCL- $b$-PEG- $b$-PCL and HDI Polyurethanes for Extrusion-Based 3D-Printing of Tough Hydrogels
}

\author{
Aysun Güney ${ }^{1}$, Christina Gardiner ${ }^{1}$, Andrew McCormack ${ }^{1}$, Jos Malda ${ }^{2,3,4}$ \\ and Dirk W. Grijpma 1,* \\ 1 Department of Biomaterials Science and Technology, Science and Technology Faculty, Technical Medical \\ Centre, University of Twente, 7500AE Enschede, The Netherlands; a.guney@utwente.nl (A.G.); \\ cgardine@students.uni-mainz.de (C.G.); mccormacka95@gmail.com (A.M.) \\ 2 Department of Orthopaedics, University Medical Center Utrecht, 3584 CX Utrecht, The Netherlands; \\ j.malda@umcutrecht.nl \\ 3 Regenerative Medicine Utrecht, Utrecht University, 3584 CX Utrecht, The Netherlands \\ 4 Faculty of Veterinary Sciences, Utrecht University, 3584 CL Utrecht, The Netherlands \\ * Correspondance: d.w.grijpma@utwente.nl; Tel.: +31-53-489-2968
}

Received: 18 September 2018; Accepted: 3 November 2018; Published: 14 November 2018

\begin{abstract}
Novel tough hydrogel materials are required for 3D-printing applications. Here, a series of thermoplastic polyurethanes (TPUs) based on poly( $\epsilon$-caprolactone)- $b$-poly(ethylene glycol)-b-poly( $\epsilon$-caprolactone) (PCL- $b$-PEG- $b$-PCL) triblock copolymers and hexamethylene diisocyanate (HDI) were developed with PEG contents varying between 30 and $70 \mathrm{~mol} \%$. These showed excellent mechanical properties not only when dry, but also when hydrated: TPUs prepared from PCL- $b$-PEG- $b$-PCL with PEG of Mn $6 \mathrm{~kg} / \mathrm{mol}\left(\mathrm{PCL}_{7}-\mathrm{PEG}_{6}-\mathrm{PCL}_{7}\right)$ took up $122 \mathrm{wt} . \%$ upon hydration and had an E-modulus of $52 \pm 10 \mathrm{MPa}$, a tensile strength of $17 \pm 2 \mathrm{MPa}$, and a strain at break of $1553 \pm 155 \%$ in the hydrated state. They had a fracture energy of $17976 \pm 3011 \mathrm{~N} / \mathrm{mm}^{2}$ and a high tearing energy of $72 \mathrm{~kJ} / \mathrm{m}^{2}$. TPUs prepared using PEG with $\mathrm{Mn}$ of $10 \mathrm{~kg} / \mathrm{mol}\left(\mathrm{PCL}_{5}-\mathrm{PEG}_{10}-\mathrm{PCL}_{5}\right.$ ) took up $534 \%$ water and were more flexible. When wet, they had an E-modulus of $7 \pm 2 \mathrm{MPa}$, a tensile strength of $4 \pm 1 \mathrm{MPa}$, and a strain at break of $147 \pm 41 \%$. These hydrogels had a fracture energy of $513 \pm 267 \mathrm{~N} / \mathrm{mm}^{2}$ and a tearing energy of $16 \mathrm{~kJ} / \mathrm{m}^{2}$. The latter TPU was first extruded into filaments and then processed into designed porous hydrogel structures by 3D-printing. These hydrogels can be used in 3D printing of tissue engineering scaffolds with high fracture toughness.
\end{abstract}

Keywords: thermoplastic polyurethanes; tough hydrogels; 3D-printing; fused deposition modeling

\section{Introduction}

Hydrogels are water-swollen polymer networks that can be used in a variety of applications in the biomedical field, such as in biomedical devices, biomedicine, sensors, and robots [1,2]. There is a great need to develop tough biodegradable hydrogels for application in the repair and regeneration of load-bearing soft tissues like cartilage, blood vessels and tendons. These tissues take up large amounts of water, are strong and resilient, have low elasticity modulus values, and at the same time are resistant to tearing [3].

While natural hydrogel materials support cell growth, cell migration, and capillary network formation in the absence of added growth factors [3], a major limitation in their application is their lack of mechanical resilience. It remains a challenge to develop robust (natural as well as synthetic) hydrogels with suitable mechanical properties in the hydrated state [4,5]. 
Several approaches have been investigated to prepare tough hydrogels. These include the preparation of hydrophilic polymer networks based on co-macromer networks, double network gels, interpenetrating multi-network gels, nanocomposite gels, slip-link gels, ionic-covalent entanglement gels, etc. [6-10]. Tough natural hydrogel networks have been prepared from mixtures of hyaluronic acid-tyramine and chondroitin sulfate-tyramine conjugates [11].

Hydrogels play an important role in bioprinting as well, but progress in this upcoming research field is limited by the lack of suitable printable hydrogels. Difficulties in the fabrication of structures by (extrusion-based) 3D printing are often related to the brittleness of the hydrogels used, resulting in structures with poor mechanical characteristics which can only be built at low resolutions $[12,13]$. To our knowledge, there are no other published examples of tough hydrogel structures prepared by $3 \mathrm{D}$ printing.

Thermoplastic polyurethanes (TPUs) are well-known in medical applications and are processable by extrusion-based 3D printing methods. They are a versatile class of polymers with high toughness and excellent control over their properties by variation of their chemical composition [14]. Poly(ethylene glycol) (PEG) is a hydrophilic polymer that is often used in biomedical engineering, and TPUs based on PEG can be designed to form physical hydrogel networks that take up large amounts of water [15]. Such hydrogels are not prepared using potentially toxic crosslinking agents [16-18], and are expected to be highly compatible with cells and tissues.

In this paper, we describe the development of tough thermoplastic hydrogels based on the formation of polyurethanes by reaction of poly( $\epsilon$-caprolactone)-b-poly(ethylene glycol)-b-poly(e-caprolactone) triblock copolymers (PCL-b-PEG- $b$-PCL) and hexamethylene diisocyanate. In the TPU multi-block copolymer the PEG component will render the material hydrophilic, while, the hydrophobic PCL component will not only allow fixation of the structure during printing by crystallization upon cooling, but will also form the physical crosslinks of the network in the hydrated state. The literature on polyurethanes prepared from PCL-PEG-PCL triblock copolymers is very limited $[19,20]$. However, the molar mass of these triblock copolymers used was very much lower than the ones we used. In this paper mechanical properties in the wet state and water uptake was not determined. In our case, we used triblock copolymers with much higher molar masses. This leads to materials with excellent processability, and very good mechanical properties in the hydrated state. We also illustrate their processability by extrusion-based 3D-printing using conventional commercially available equipment.

\section{Materials and Methods}

\subsection{Materials}

Polyethylene glycol (PEG) with number average molecular weights (Mn) of $6 \mathrm{~kg} / \mathrm{mol}, 10 \mathrm{~kg} / \mathrm{mol}$ and $14 \mathrm{~kg} / \mathrm{mol}$, 1,4-diazabicyclo[2.2.2]octane (DABCO) and hexamethylene diisocyanate (HDI) were purchased from Sigma Aldrich (St. Louis, MO, USA). PEG was dried by azeotropic distillation with toluene before use. Diphenyl phosphate (DPP) was obtained from Tokyo Chemical Industry (Oxford, UK). $\epsilon$-caprolactone (CL) monomer was obtained from Acros Organics (Geel, Belgium) and was purified by drying over $\mathrm{CaH}_{2}$ (Merck, Darmstadt, Germany) and distillation under vacuum before use. Tetrahydrofuran (THF, from Merck, Germany) was dried over molecular sieves before use. Dichloromethane, methanol and diethyl ether were obtained from VWR Chemicals (Amsterdam, The Netherlands) and used as received. Deuterated chloroform $\left(\mathrm{CDCl}_{3}\right)$ was purchased from Sigma Aldrich (USA).

\subsection{Methods}

\subsubsection{Synthesis of PCL-b-PEG- $b$-PCL and TPU-(PCL- $b$-PEG- $b$-PCL) Polymers}

PCL- $b$-PEG- $b$-PCL triblock copolymers with targeted molecular weights of $20 \mathrm{~kg} / \mathrm{mol}$ were prepared by ring opening polymerization (ROP) of $\epsilon$-CL using PEG as an initiator and DPP as a catalyst 
as illustrated in Figure 1a. The molar ratio of DPP catalyst to PEG initiator was 1:1. The polymerizations were carried out under inert conditions (using argon gas) at $70{ }^{\circ} \mathrm{C}$ on a $50 \mathrm{~g}$ scale in 3-necked glass flasks equipped with mechanical stirrers. In a typical polymerization procedure, the dried PEG is introduced into the flask and heated under vacuum to $130^{\circ} \mathrm{C}$ for $3 \mathrm{~h}$. The temperature is then decreased to $70{ }^{\circ} \mathrm{C}$, and freshly distilled $\epsilon$-CL and DPP are added. While stirring, the reaction mixture was let to polymerize under at $70{ }^{\circ} \mathrm{C}$ for $96 \mathrm{~h}$. The obtained polymer was dissolved in dichloromethane, precipitated in cold methanol and dried under vacuum.

A series of PCL- $b$-PEG- $b$-PCL triblock copolymers $\left(\mathrm{PCL}_{7}-\mathrm{PEG}_{6}-\mathrm{PCL}_{7}, \mathrm{PCL}_{5}-\mathrm{PEG}_{10}-\mathrm{PCL}_{5}\right.$, $\left.\mathrm{PCL}_{3}-\mathrm{PEG}_{14}-\mathrm{PCL}_{3}\right)$ with different $\mathrm{PCL}$ block lengths $\left(\mathrm{PCL}_{7}, \mathrm{PCL}_{5}, \mathrm{PCL}_{3}\right)$ was prepared in this manner

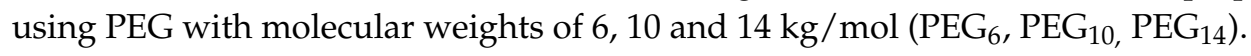

Thermoplastic polyurethanes (TPUs, TPU-(PCL- $b$-PEG- $b$-PCL) were prepared by reacting the hydroxyl end-groups of the PCL- $b$-PEG- $b$-PCL triblock copolymers with hexamethylene diisocyanate (HDI) using 1,4-diazabicyclo[2.2.2] octane (DABCO) as a catalyst, see Figure 1b. The dried triblock copolymers were dissolved in anhydrous THF at a concentration of $70 \mathrm{~g} / \mathrm{mL}$ at $70{ }^{\circ} \mathrm{C}$ in glass 3-necked flasks under argon, after which DABCO ( $2 \mathrm{wt} . \%$ relative to the polymer) was added.

Hexamethylene diisocyanate was then added slowly to the solution at a rate of 10 drops/10 min; the ratio of hydroxyl groups to isocyanate groups was 1:3. The reaction was continued for another 24 $\mathrm{h}$. After slowly cooling to room temperature, the polymer solution precipitated in cold diethyl ether. After washing with water, the obtained polymer was dried under vacuum.

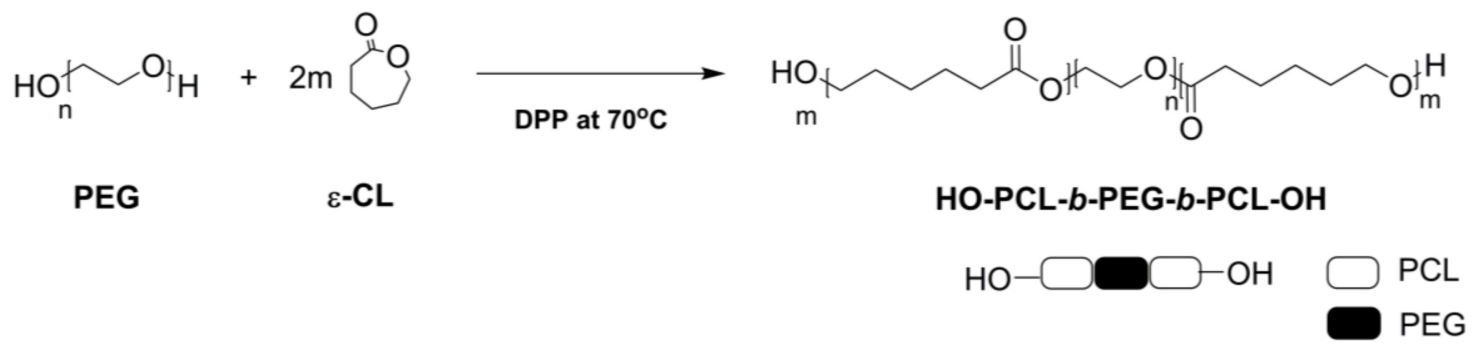

(a)
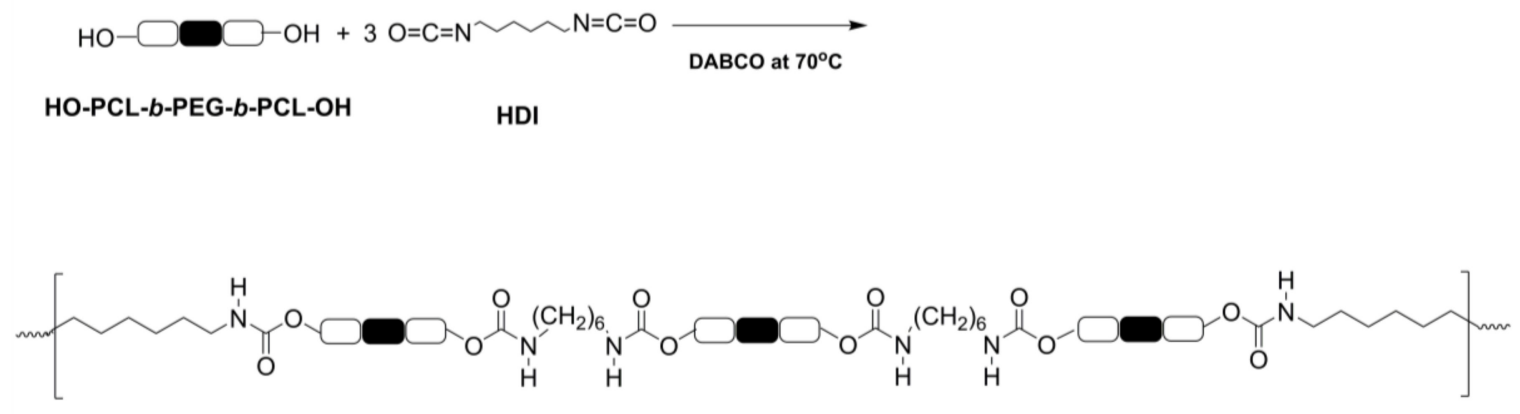

TPU-(PCL-b-PEG-b-PCL)

(b)

Figure 1. Synthesis of (a) hydroxyl-group terminated HO-PCL-b-PEG-b-PCL-OH triblock copolymers and (b) corresponding TPU-(PCL- $b$-PEG- $b$-PCL) thermoplastic polyurethane multi-block copolymers.

\subsubsection{Characterization of PCL-b-PEG- $b$-PCL and TPU-(PCL- $b$-PEG- $b$-PCL) Polymers}

The chemical composition and the molar mass (Mn) of the triblock copolymers and the thermoplastic polyurethanes were determined by NMR-spectroscopy using a $400 \mathrm{MHz}{ }^{1} \mathrm{H}-\mathrm{NMR}$ apparatus (Bruker Ascend 400, Bruker, San Jose, CA, USA). ${ }^{13} \mathrm{C}-\mathrm{NMR}$ experiments at $100 \mathrm{MHz}$ (Bruker Ascend 400) were conducted as well. The polymers were dissolved in deuterated chloroform, although it should be noted that in the case of the TPUs, a very small amount of minute fragments 
seemed to not have dissolved. These microgel particles could be the result of allophanate side reactions [21]. The chemical structure of the TPU block copolymers was additionally confirmed by ATR-FTIR using a Perkin Elmer Spectrum Two ${ }^{\text {TM }}$ FTIR Spectrometer (Waltham, MA, USA). Spectra of polymer films were obtained using 32 scans at a resolution of $4 \mathrm{~cm}^{-1}$.

The inherent viscosity of the polymers was determined using a capillary Ubbelohde viscometer at $25{ }^{\circ} \mathrm{C}$ at a concentration of $0.1 \mathrm{~g} / \mathrm{dL}$ in chloroform. Here too, very small amounts of minute swollen polymer fragments could be observed in the polymer solutions.

Differential Scanning Calorimetry (DSC) analyses were performed using a Pyris 1 DSC (Perkin Elmer, Waltham, MA, USA). Polymer samples (5-10 mg) were heated in stainless steel pans from $-100{ }^{\circ} \mathrm{C}$ to $250{ }^{\circ} \mathrm{C}$ at a rate of $10^{\circ} \mathrm{C} / \mathrm{min}$, rapidly cooled to $-100{ }^{\circ} \mathrm{C}$ at $20^{\circ} \mathrm{C} / \mathrm{min}$, after which a second scan was taken at a rate $10^{\circ} \mathrm{C} / \mathrm{min}$. The glass transition $(\mathrm{Tg})$ and the melting temperature $(\mathrm{Tm})$ were determined using data from the second heating run.

\subsubsection{Physical and Mechanical Properties of PCL-b-PEG- $b$-PCL and TPU-(PCL-b-PEG-b-PCL)} Polymers

Polymer films were fabricated by compression molding the polymers into sheets at $70{ }^{\circ} \mathrm{C}$ for 10 min using a hot press (THB 400, Fontijne BV, Barendrecht, The Netherlands), followed by cooling to room temperature. The thickness of the films was 200 to $300 \mu \mathrm{m}$. The water uptake of the TPU-(PCL- $b$-PEG- $b$-PCL) films (approximately $200 \mathrm{mg}$ ) was determined after equilibrium swelling in an excess of water $(15 \mathrm{~mL})$ at $37^{\circ} \mathrm{C}$ using the following equation:

$$
\text { water uptake }=\left(\frac{m_{w e t}-m_{d r y}}{m_{d r y}}\right) \times 100
$$

where $m_{d r y}$ and $m_{w e t}$ are the mass of the dry film and that after it has swollen to equilibrium, respectively. The surface of the water-swollen samples was blotted prior to the measurement of their mass.

The tensile properties and the resistance to tearing of the TPU-(PCL-b-PEG-b-PCL) films in the dry and wet state were determined at room temperature using a universal tensile tester (Zwick ZO20, Ulm, Germany) equipped with a $500 \mathrm{~N}$ load cell. Tensile testing was done at room temperature in accordance to ASTM D882-91. Specimens measuring $100 \times 5 \mathrm{~mm}^{2}$ were punched out from the films and tested at a crosshead speed of $50 \mathrm{~mm} / \mathrm{min}$. The E-modulus, the yield stress $\left(\sigma_{\text {yield }}\right)$, the elongation at yield $\left(\epsilon_{\text {yield }}\right)$, the maximum tensile stress $\left(\sigma_{\max }\right)$, the elongation at the break $\left(\epsilon_{\text {break }}\right)$ and the toughness of the specimens ( $\mathrm{W}$ in $\mathrm{N} / \mathrm{mm}^{2}$, the surface area below the stress-strain curve), were determined from the stress-strain curves. The yield stress and -strain were determined from the intersection of the tangents to the stress-strain curves.

The average-(TPS $\left.\mathrm{Tve}_{\mathrm{av}}\right)$ and maximal tear propagation strength $\left(\mathrm{TPS}_{\max }\right)$ of the polymers were determined according to ASTM D1938 at a crosshead speed of $250 \mathrm{~mm} / \mathrm{min}$ using trouser tear specimens $\left(75 \times 25 \mathrm{~mm}^{2}\right.$, with a $50 \mathrm{~mm}$ incision). The tearing energy $\left(G\right.$ expressed in $\left.\mathrm{kJ} / \mathrm{m}^{2}\right)$ was calculated according to [22]:

$$
G=\frac{2 F}{t}
$$

where $F$ is the average tearing force and $t$ is the thickness of the specimen.

\subsubsection{Fabrication of Designed Structures by Fused Deposition Modelling (FDM)}

Compression molded polymer films were cut into small pieces and extruded at $120{ }^{\circ} \mathrm{C}$ into filaments with a diameter of approximately $2.5 \mathrm{~mm}$ using a Noztek Pro filament extruder (Noztek, Shoreham, UK). The extruded filaments were collected on a rotating spindle and air-cooled to room temperature. The resulting filaments were then further processed by FDM into designed structures using an Ultimaker $2^{+}$3D Printer (Ultimaker, Geldermalsen, The Netherlands). Printing was done at $180^{\circ} \mathrm{C}$ through a $0.4 \mathrm{~mm}$ nozzle at a printing speed of $1 \mathrm{~mm} / \mathrm{s}$, the building plate was at 
room temperature. The fabricated structures were imaged by scanning electron microscopy (HR-SEM, Zeiss 1550, Jena, Germany) after sputter-coating with gold.

\section{Results}

\subsection{PCL-b-PEG-b-PCL Triblock Copolymers}

Triblock copolymers were prepared by the ring opening polymerization of $\epsilon$-CL with PEG as an initiator and DPP as a catalyst as described earlier. ${ }^{1} \mathrm{H}-\mathrm{NMR}$ analysis was used to determine monomer conversion, composition and molar mass of the triblock copolymers formed.

Figure 2a shows a characteristic ${ }^{1} \mathrm{H}-\mathrm{NMR}$ spectrum of a $\mathrm{PCL}_{5}-\mathrm{PEG}_{10}-\mathrm{PCL}_{5}$ triblock copolymer obtained after polymerization, precipitation and drying. The sharp singlet at $3.65 \mathrm{ppm}(\mathbf{a})$ corresponds to the methylene protons of the PEG block. The triplet at $2.29 \mathrm{ppm}$ corresponds to the -O-CO- $\mathrm{CH}_{2}-\mathrm{CH}_{2}-\mathrm{CH}_{2}-\mathrm{CH}_{2}-\mathrm{CH}_{2}-(\mathbf{b})$ methylene protons of the PCL blocks, the multiplet from 1.59 to 1.68 ppm to the $-\mathrm{O}-\mathrm{CO}-\mathrm{CH}_{2}-\mathrm{CH}_{2}-\mathrm{CH}_{2}-\mathrm{CH}_{2}-\mathrm{CH}_{2}-$ (c) methylene protons of the PCL blocks, the multiplet from 1.33 to 1.41 to the $-\mathrm{O}-\mathrm{CO}-\mathrm{CH}_{2}-\mathrm{CH}_{2}-\mathrm{CH}_{2}-\mathrm{CH}_{2}-\mathrm{CH}_{2}-(\mathrm{d})$ methylene protons of the PCL blocks, and the triplet at $4.05 \mathrm{ppm}$ to the $-\mathrm{O}-\mathrm{CO}-\mathrm{CH}_{2}-\mathrm{CH}_{2}-\mathrm{CH}_{2}-\mathrm{CH}_{2}-\mathrm{CH}_{2}-(\mathbf{e})$ methylene protons of the PCL blocks. From the integral values of these peaks, the composition of the triblock copolymers can be calculated. Furthermore, knowing the molar mass of the PEG initiator as determined by ${ }^{1} \mathrm{H}-\mathrm{NMR}$ and assuming each PEG chain initiates the polymerization of $\mathrm{CL}$, the molar mass of the PCL blocks and that of the triblock copolymer can be determined. An overview of the characteristics of the synthesized triblock copolymers is presented in Table 1. It can be seen that the molar mass and composition of the triblock copolymers was close to the targeted values.

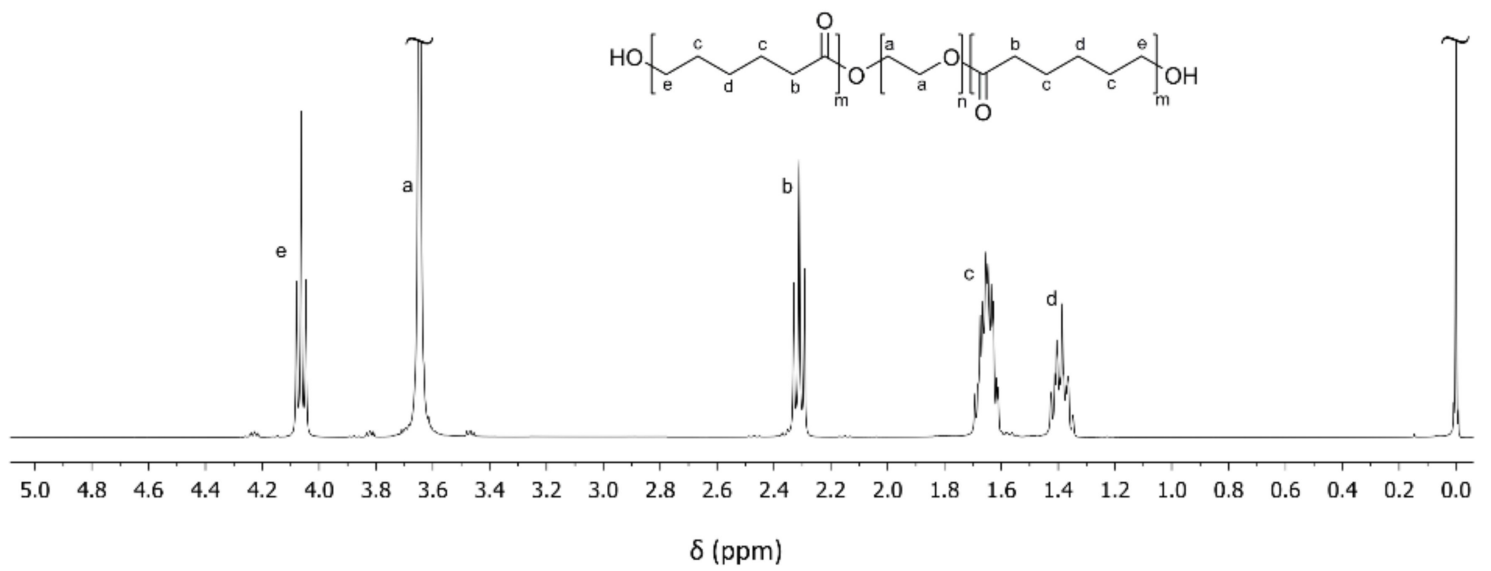

(a)
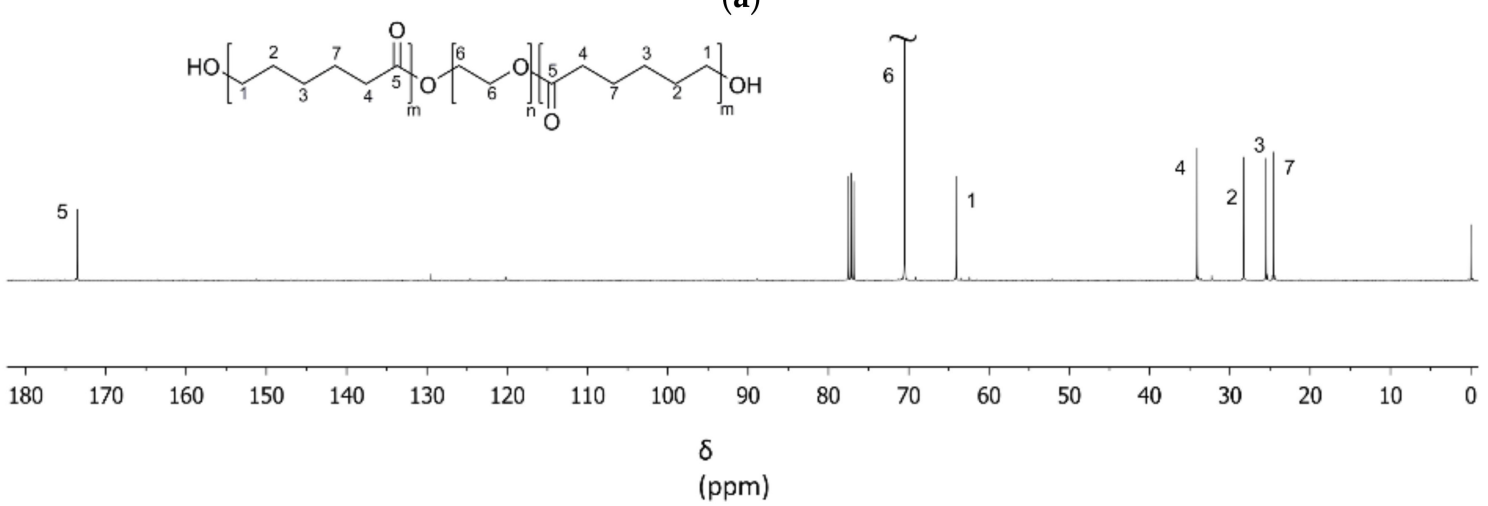

(b)

Figure 2. Characteristic (a) ${ }^{1} \mathrm{H}-\mathrm{NMR}$ and (b) ${ }^{13} \mathrm{C}-\mathrm{NMR}$ spectra of $\mathrm{PCL}_{5}-\mathrm{PEG}_{10}-\mathrm{PCL}_{5}$ triblock copolymers after purification by precipitation. 
Table 1. The composition and PEG and PCL block lengths of synthesized PCL- $b$-PEG- $b$-PCL triblock copolymers as determined by ${ }^{1} \mathrm{H}-\mathrm{NMR}$ after purification.

\begin{tabular}{cccccc}
\hline \multirow{2}{*}{ Target Structure } & $\mathbf{M}_{\mathbf{n}}$ of PEG Block $^{\mathbf{a}}$ & CL Conversion $^{\mathbf{b}}$ & $\mathbf{M}_{\mathbf{n}}$ of PCL Blocks & PEG Content & $\mathbf{M}_{\mathbf{n}}$ of Triblock Copolymer \\
\cline { 2 - 6 } & $\mathbf{( k g / m o l )}$ & $\mathbf{( \% )}$ & $\mathbf{( k g / m o l )}$ & $\mathbf{( m o l} \mathbf{\%})$ & $\mathbf{( k g / m o l )}$ \\
\hline PCL $_{3}-\mathrm{PEG}_{14}-\mathrm{PCL}_{3}$ & 13.9 & 99.2 & $\frac{1}{2} \times 5.9$ & 70.2 & 19.8 \\
PCL $_{5}-\mathrm{PEG}_{10}-\mathrm{PCL}_{5}$ & 9.9 & 99.4 & $\frac{1}{2} \times 10.0$ & 49.8 & 19.9 \\
PCL $_{7}-\mathrm{PEG}_{6}-\mathrm{PCL}_{7}$ & 5.9 & 99.8 & $\frac{1}{2} \times 14.1$ & 29.5 & 20.0 \\
\hline
\end{tabular}

${ }^{a} \mathrm{M}_{n}$ of PEG used as an initiator in the ring opening polymerization of CL. ${ }^{b} \mathrm{CL}$ conversion was determined before purification.

The table also shows that the conversion of $C L$ was very high. These values were determined from ${ }^{1} \mathrm{H}-\mathrm{NMR}$ spectra of the triblock copolymers before precipitation and drying (spectra not shown). The $\varepsilon-\mathrm{CL}$ conversion can be calculated from the integral values of the characteristic -O-CO- $\mathrm{CH}_{2}-\mathrm{CH}_{2}-\mathrm{CH}_{2}-\mathrm{CH}_{2}-\mathrm{CH}_{2}-$ triplet of the $\varepsilon-\mathrm{CL}$ monomer at $2.47 \mathrm{ppm}$ and the integral values of the characteristic $-\mathrm{O}-\mathrm{CO}-\mathrm{CH}_{2}-\mathrm{CH}_{2}-\mathrm{CH}_{2}-\mathrm{CH}_{2}-\mathrm{CH}_{2}$ - triplet of the PCL blocks (b) at $2.31 \mathrm{ppm}$.

The ${ }^{13} \mathrm{C}$-NMR spectrum in Figure $2 \mathrm{~b}$ illustrates the block structure of the synthesized triblock copolymers. In the spectrum, the peak at $70.69 \mathrm{ppm}$ corresponds to the methylene carbon atoms of PEG (6). The peak at $64.28 \mathrm{ppm}$ corresponds to the $-\mathrm{O}-\mathrm{CO}-\mathrm{CH}_{2}-\mathrm{CH}_{2}-\mathrm{CH}_{2}-\mathrm{CH}_{2}-\mathrm{CH}_{2}-$ (1), the peak at $28.48 \mathrm{ppm}$ to the $-\mathrm{O}-\mathrm{CO}-\mathrm{CH}_{2}-\mathrm{CH}_{2}-\mathrm{CH}_{2}-\mathrm{CH}_{2}-\mathrm{CH}_{2}-$ (2), the peak at $25.66 \mathrm{ppm}$ to the $-\mathrm{O}-\mathrm{CO}-\mathrm{CH}_{2}-\mathrm{CH}_{2}-\mathrm{CH}_{2}-\mathrm{CH}_{2}-\mathrm{CH}_{2}-$ (3), the peak at $34.25 \mathrm{ppm}$ to the $-\mathrm{OC}-\mathrm{O}-\mathrm{CH}_{2}-\mathrm{CH}_{2}-\mathrm{CH}_{2}-\mathrm{CH}_{2}-\mathrm{CH}_{2}-$ (4) and the peak at $24.71 \mathrm{ppm}$ to the $-\mathrm{O}-\mathrm{CO}-\mathrm{CH}_{2}-\mathrm{CH}_{2}-\mathrm{CH}_{2}-\mathrm{CH}_{2}-\mathrm{CH}_{2}-(7)$ methylene carbons of the PCL blocks of the triblock copolymer. The peak at 173.64 characterizes the carbonyl carbon atom $-\mathrm{O}-\mathrm{CO}-\mathrm{CH}_{2}-\mathrm{CH}_{2}-\mathrm{CH}_{2}-\mathrm{CH}_{2}-\mathrm{CH}_{2}-(5)$ of the PCL blocks of the triblock copolymer.

An overview of the thermal characteristics of the prepared triblock copolymers is given in Table 2. It can be seen that in the dry state, a $\mathrm{Tg}$ of approximately $-60^{\circ} \mathrm{C}$ can be observed. This temperature is close to the Tg of both PEG and PCL (respective values are approximately $-55^{\circ} \mathrm{C}$ and $-60^{\circ} \mathrm{C}$ ). Distinct glass transition temperatures corresponding to the different amorphous phases of PEG and PCL could thus not be observed. In addition, single peak melting temperatures were seen, with Tm values close to $50{ }^{\circ} \mathrm{C}$. The values of the melting enthalpies seem to decrease with decreasing PEG content. It was observed that upon cooling, the triblock copolymers crystallize at temperatures between 15 and $20{ }^{\circ} \mathrm{C}$. The triblock copolymers with the lower PEG contents had the lower crystallization temperatures.

Table 2. Thermal characteristics of PCL- $b$-PEG- $b$-PCL triblock copolymers in the dry state.

\begin{tabular}{lcccc}
\hline & $\mathbf{T g}\left({ }^{\circ} \mathbf{C}\right)$ & $\mathbf{T c}\left({ }^{\circ} \mathrm{C}\right)$ & $\operatorname{Tm}\left({ }^{\circ} \mathbf{C}\right)$ & $\Delta \mathbf{H}(\mathbf{J} / \mathbf{g})$ \\
\hline PCL $_{3}-\mathrm{PEG}_{14}-\mathrm{PCL}_{3}$ & -61 & 20 & 51 & 115 \\
$\mathrm{PCL}_{5}-\mathrm{PEG}_{10}-\mathrm{PCL}_{5}$ & -64 & 17 & 52 & 101 \\
$\mathrm{PCL}_{7}-\mathrm{PEG}_{6}-\mathrm{PCL}_{7}$ & -67 & 15 & 47 & 69 \\
\hline
\end{tabular}

Films prepared by compression molding of these triblock copolymers were very fragile and fragmented; their mechanical properties were negligible. Furthermore, upon immersion in water they further fell apart into small pieces.

\subsection{TPU-(PCL-b-PEG-b-PCL) Multi-Block Copolymers}

TPUs based on the PCL- $b$-PEG- $b$-PCL triblock copolymers were successfully synthesized by step growth polymerization of the hydroxyl-terminated PCL- $b$-PEG- $b$-PCL triblock copolymers with HDI. These polymerizations led to multi-block polyurethanes with high molecular weights. The inherent viscosities of TPU-(PCL $\left.-\mathrm{PEG}_{14}-\mathrm{PCL}_{3}\right)$, TPU-(PCL $\left.-\mathrm{PEG}_{10}-\mathrm{PCL}_{5}\right)$ and TPU-(PCL $\left.-\mathrm{PEG}_{6}-\mathrm{PCL}_{7}\right)$ were respectively $1.2,1.2$ and $1.4 \mathrm{dL} / \mathrm{g}$. 
Figure 3 shows the characteristic ${ }^{1} \mathrm{H}-\mathrm{NMR}$ spectra of TPUs based on PCL- $b$-PEG- $b$-PCL triblock copolymer after purification. All individual signals that correspond to the PEG and PCL segments of the consistent triblock copolymer, as well as those of the formed urethane bonds, can be observed.

The sharp singlet at $\delta=3.65 \mathrm{ppm}$ is due to the methylene protons of the PEG component (a) of the triblock copolymer. The triplets at $\delta=4.06,2.31$ and the multiplets at $\delta=1.65$ and $1.40 \mathrm{ppm}$ relate respectively to the (e), (b), (c) and (d) methylene protons of the PCL block in the block copolymer. The urethane group, $-\mathrm{OOCNH}-$, is clearly presented at $\delta=4.68$ (f) $\mathrm{ppm}$.
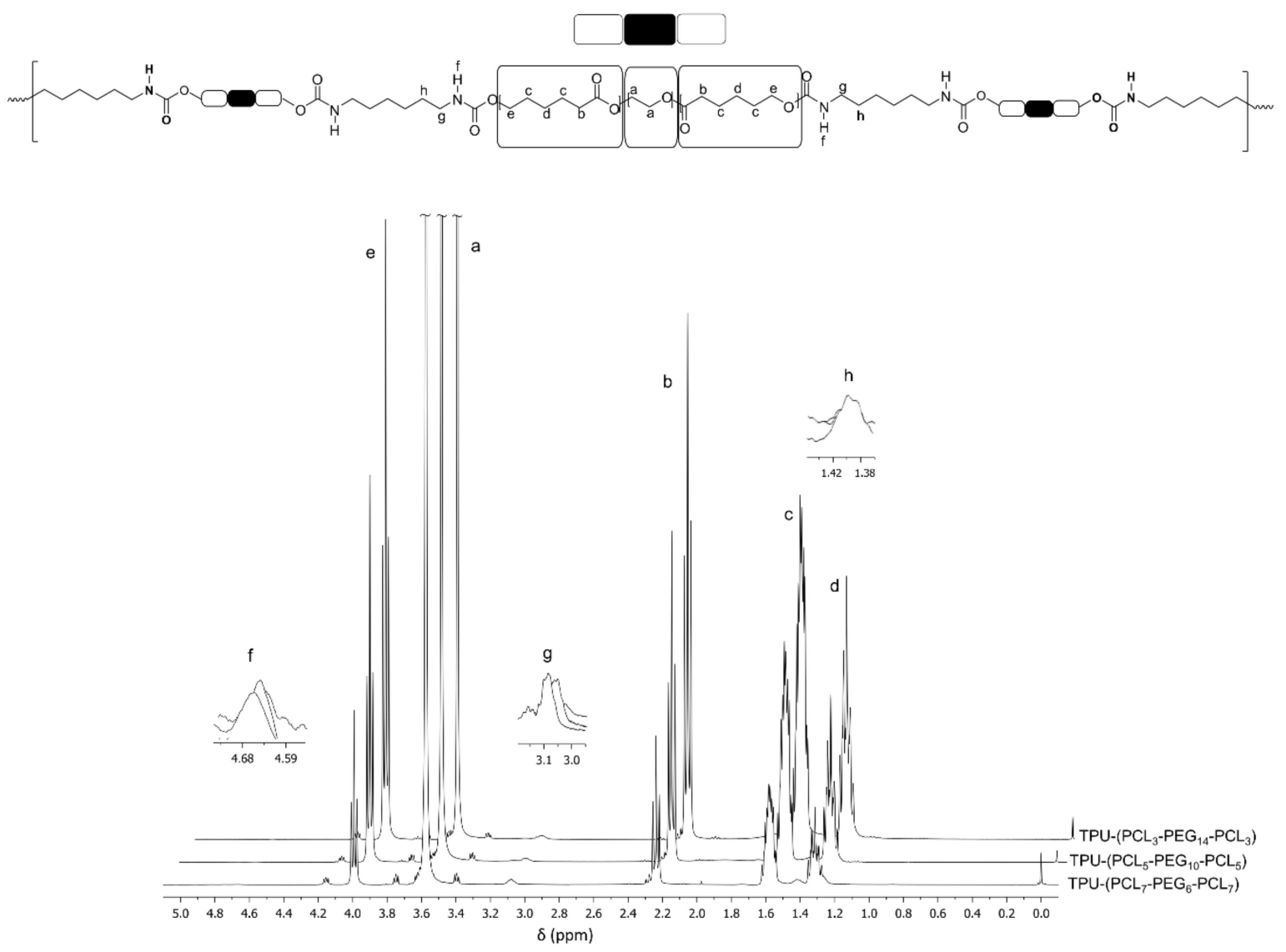

Figure 3. ${ }^{1} \mathrm{H}-\mathrm{NMR}$ spectra of TPU multi-block copolymers based on different PCL- $b$-PEG- $b$-PCL triblock copolymers.

Additionally, FTIR analyses indicated the successful formation of urethane bonds upon reaction of the terminal hydroxyl groups of the triblock copolymers with hexamethylene diisocyanate. Figure 4 shows the FTIR spectra from $4000-600 \mathrm{~cm}^{-1}$ of the different synthesized and purified TPUs. The presence of urethane bonds is confirmed by the presence of a broad peak at $3700-3400 \mathrm{~cm}^{-1}$ that can be ascribed to $\mathrm{N}-\mathrm{H}$ stretching vibrations. The absorption peak at $1270 \mathrm{~cm}^{-1}$ arises from contributions of the $\mathrm{N}-\mathrm{H}$ in-plane bending and the $\mathrm{C}-\mathrm{N}$ stretching vibrations. The absorption peak at $1244 \mathrm{~cm}^{-1}$ corresponds to the $\mathrm{C}-\mathrm{O}$ stretching vibration mode of urethane bonds. The absence of a characteristic peak related to NCO isocyanate groups around $2270 \mathrm{~cm}^{-1}$ indicates that all NCO groups of HDI have reacted with the terminal $\mathrm{OH}$ groups of the precursor triblock copolymers.

Besides this, the absorption peaks at 2939 and $2864 \mathrm{~cm}^{-1}$ can be attributed to anti-symmetric and symmetric modes of the $\mathrm{C}-\mathrm{H}$ stretching vibrations in the PEG and PCL segments. TPU multi-block copolymers based on PCL- $b$-PEG- $b$-PCL triblock copolymers containing higher PEG contents showed higher absorption peaks for the symmetric mode of the $\mathrm{C}-\mathrm{H}$ stretching vibrations at $2864 \mathrm{~cm}^{-1}$. In addition, the $\mathrm{C}-\mathrm{O}-\mathrm{C}$ stretching vibration in the PEG part shows an absorption peak at $1100 \mathrm{~cm}^{-1}$. The $\mathrm{C}=\mathrm{O}$ stretching vibration displays an absorption peak at $1723 \mathrm{~cm}^{-1}$; copolymers containing higher 
contents of PCL content show higher intensities of the $C=O$ peaks. The absorption peaks at 1468,1365 and $1348 \mathrm{~cm}^{-1}$ are related to $\mathrm{CH}_{2}$ bending and scissoring vibrations of the methylene groups in the PEG and PCL segments.

These FTIR results, together with the ${ }^{1} \mathrm{H}-\mathrm{NMR}$ and ${ }^{13} \mathrm{C}-\mathrm{NMR}$ data, confirm the successful formation of TPU-(PCL- $b$-PEG- $b$-PCL) multi-block copolymers.

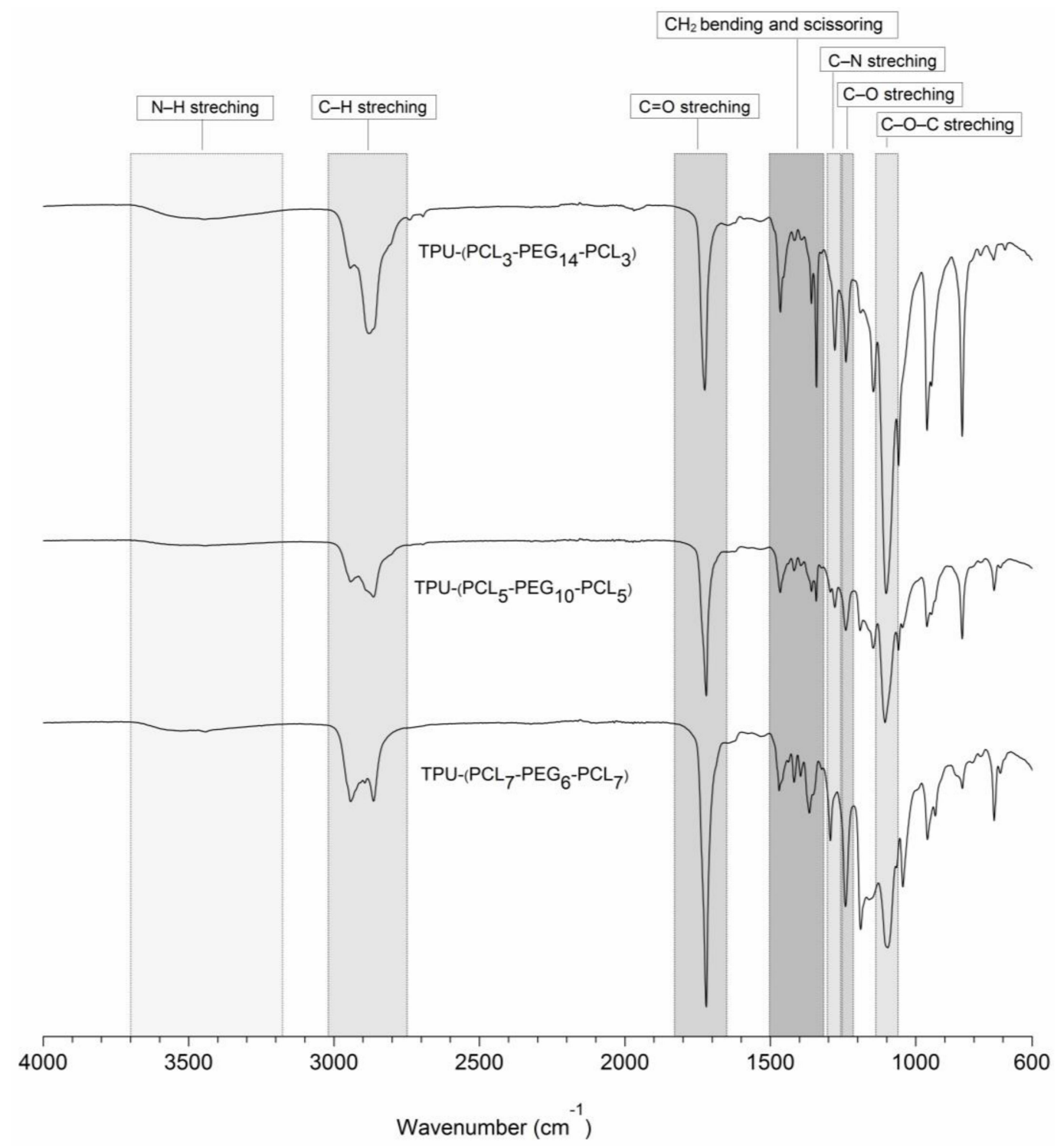

Figure 4. FTIR spectra of synthesized TPUs based on PCL- $b$-PEG- $b$-PCL triblock copolymers.

An overview of the thermal characteristics of the obtained TPUs is listed in Table 3. A typical DSC graph is presented in Figure 5. It can be seen that in the dry state, a single Tg of approximately $-60{ }^{\circ} \mathrm{C}$ can also be observed. In addition, single peak melting temperatures close to $-50^{\circ} \mathrm{C}$ were seen. The values of the melting enthalpies decrease with decreasing PEG content. It can be seen that the crystallization temperatures of the dry TPU-(PCL- $b$-PEG- $b$-PCL) multi-block copolymers is slightly above or close to room temperature. This implies that upon thermal processing and cooling to room temperature, crystallization will occur at maximum rates. Water uptake (equilibrium water uptake is reached in 3 days) is mainly due to the hydrophilic PEG component of the TPU-(PCL- $b$-PEG- $b$-PCL). The higher the PEG fraction in the TPU is, the higher the water uptake is. The melting temperatures and melting enthalpies of the TPUs in the wet state are mainly due to the PCL fraction and are significantly reduced when compared to the values in the dry state. 


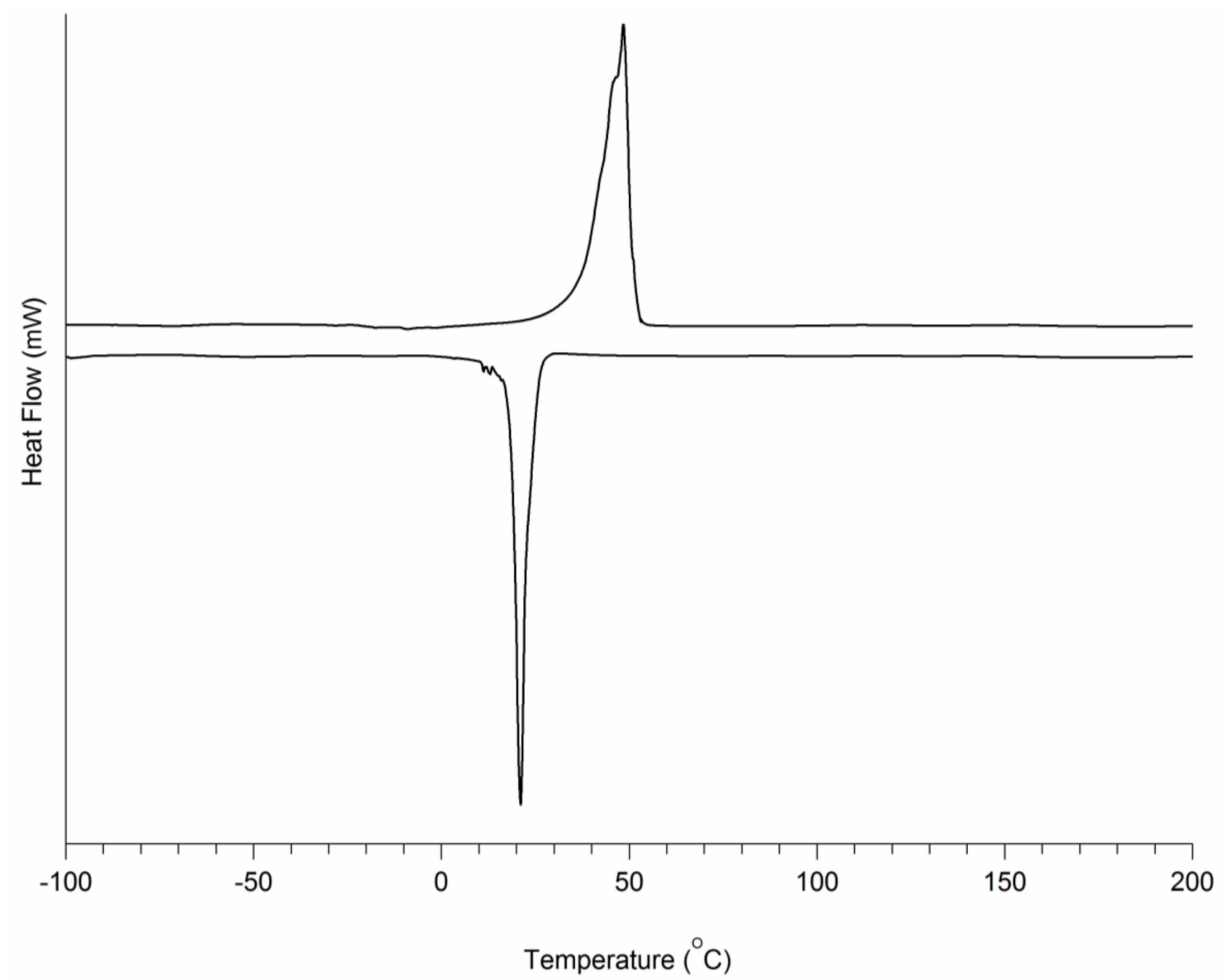

Figure 5. DSC thermogram of TPU-(PCL5 $\left.-\mathrm{PEG}_{10}-\mathrm{PCL}_{5}\right)$ in the dry state. The sample was heated from $-100{ }^{\circ} \mathrm{C}$ to $200{ }^{\circ} \mathrm{C}$ at $10 / \mathrm{min}$, then cooled at a rate of $10 / \mathrm{min}$.

Table 3. Thermal characteristics of TPU-(PCL- $b$-PEG- $b-\mathrm{PCL})$ in the dry and in the wet state.

\begin{tabular}{|c|c|c|c|c|c|c|}
\hline & & Water Uptake (wt.\%) & $\operatorname{Tg}\left({ }^{\circ} \mathrm{C}\right)$ & Tc $\left({ }^{\circ} \mathrm{C}\right)$ & $\operatorname{Tm}\left({ }^{\circ} \mathrm{C}\right)$ & $\Delta \mathrm{H}(\mathrm{J} / \mathrm{g})$ \\
\hline \multirow{3}{*}{ DRY } & TPU-(PCL $\left.3-\mathrm{PEG}_{14}-\mathrm{PCL}_{3}\right)$ & - & -58 & 26 & 48 & 100 \\
\hline & TPU-(PCL $\left.-\mathrm{PEG}_{10}-\mathrm{PCL}_{5}\right)$ & - & -60 & 21 & 49 & 81 \\
\hline & TPU-(PCL $\left.-\mathrm{PEG}_{6}-\mathrm{PCL}_{7}\right)$ & - & -60 & 23 & 51 & 37 \\
\hline \multirow{3}{*}{ WET } & TPU-(PCL $\left.3-\mathrm{PEG}_{14}-\mathrm{PCL}_{3}\right)^{\mathrm{a}}$ & soluble & - & - & - & - \\
\hline & TPU-(PCL - PEG $\left._{10}-\mathrm{PCL}_{5}\right)$ & 534 & -73 & $\mathrm{~b}$ & 42 & 10 \\
\hline & TPU-(PCL $\left.7-\mathrm{PEG}_{6}-\mathrm{PCL}_{7}\right)$ & 122 & -69 & $\mathrm{~b}$ & 49 & 19 \\
\hline
\end{tabular}

${ }^{\text {a }}$ Soluble in water. ${ }^{\mathrm{b}}$ Only crystallization of water can be discerned.

The tensile stress-strain behavior of the TPUs under dry and hydrated conditions are presented in Figure 6, quantitative data are given in Table 4. Figure 6a shows that under dry conditions all TPUs show plastic deformation and very high elongations at break. Values of the elasticity modulus, tensile yield stress and maximum tensile stress of the TPUs increase with PCL content. In addition, tensile toughness, the area under the stress-strain curves, increases significantly with PCL content (see Table 4).

Upon uptake of water, the elasticity modulus decreases. TPU-(PCL $\left.-\mathrm{PEG}_{10}-\mathrm{PCL}_{5}\right)$ with a PEG content of $50 \%$ takes up $534 \%$ water. Values of its elasticity modulus, yield strength, maximum tensile strength, elongation at break and toughness significantly decrease when compared to the dry state. By comparison, TPU-(PCL $\left.-\mathrm{PEG}_{10}-\mathrm{PCL}_{5}\right)$ takes up $122 \%$ water and only the value of the elasticity modulus decreases, while yield strength, maximum tensile strength, elongation at break and toughness change only to a limited extent. TPU-( $\left.\mathrm{PCL}_{3}-\mathrm{PEG}_{14}-\mathrm{PCL}_{3}\right)$ multi-block copolymers dissolve in water. Note that the swollen hydrogels remain stable for more than one month. 


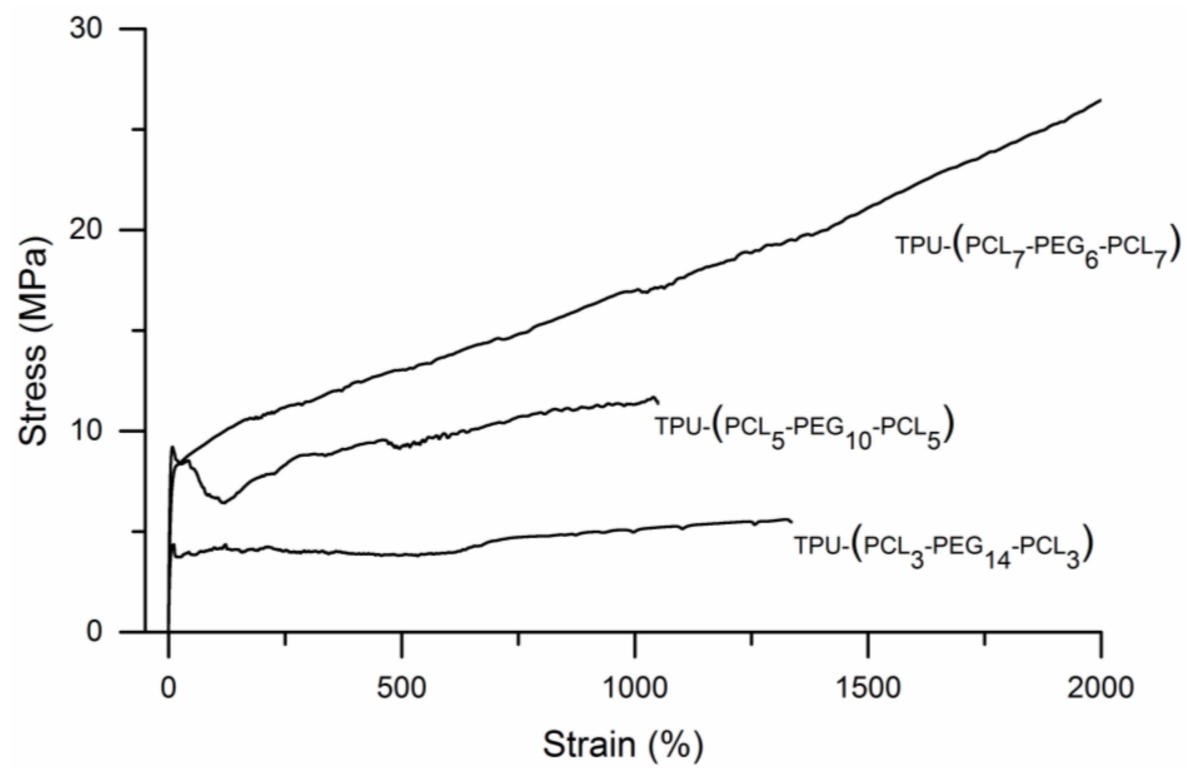

(a)

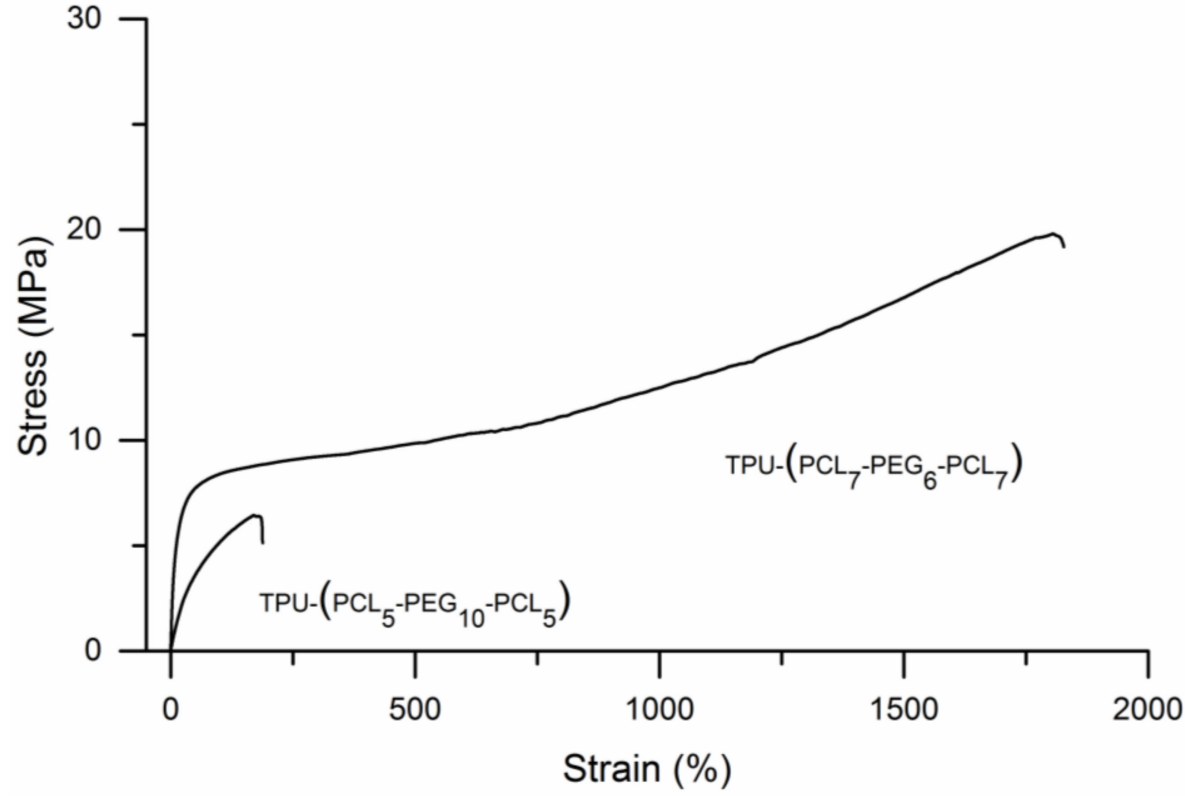

(b)

Figure 6. Stress-strain curves of the different TPU-(PCL-b-PEG- $b$-PCL) multi-block copolymers with different compositions: (a) Experiments conducted using dry specimens and (b) experiments conducted using wet specimens. The water uptake of TPU-(PCL $\left.-\mathrm{PEG}_{10}-\mathrm{PCL}_{5}\right)$ was $534 \%$, the water uptake of TPU-(PCL $\left.-\mathrm{PEG}_{6}-\mathrm{PCL}_{7}\right)$ was $122 \%$.

Table 4. Tensile properties of TPU-(PCL- $b$-PEG- $b$-PCL) multi-block copolymers in the dry and in the wet state. $(n=5$, average \pm SD).

\begin{tabular}{|c|c|c|c|c|c|c|c|c|}
\hline & PEG/PCL & Water Uptake & $\mathbf{E}$ & $\sigma_{\max }$ & $\epsilon_{\text {break }}$ & $\sigma_{\text {yield }}$ & $\epsilon_{\text {yield }}$ & $\mathbf{W}_{\text {tensile }}$ \\
\hline & $(\mathrm{mol} / \mathrm{mol})$ & (wt.\%) & (MPa) & (MPa) & $(\%)$ & (MPa) & $(\%)$ & $\left(\mathrm{N} / \mathrm{mm}^{2}\right)$ \\
\hline TPU-(PCL $\left.-\mathrm{PEG}_{14}-\mathrm{PCL}_{3}\right)$ & $70.2 / 29.8$ & dry & $100 \pm 15$ & $6.1 \pm 0.4$ & $1080 \pm 242$ & $3.7 \pm 0.5$ & $5.1 \pm 0.2$ & $6244 \pm 725$ \\
\hline TPU-(PCL $\left.-\mathrm{PEG}_{10}-\mathrm{PCL}_{5}\right)$ & $49.8 / 50.2$ & dry & $176 \pm 16$ & $8 \pm 2$ & $766 \pm 282$ & $7.5 \pm 1$ & $3.2 \pm 0.6$ & $5865 \pm 3224$ \\
\hline TPU-(PCL $\left.-\mathrm{PEG}_{6}-\mathrm{PCL}_{7}\right)$ & $29.5 / 70.5$ & dry & $103 \pm 16$ & $15 \pm 7$ & $1566 \pm 326$ & $6.9 \pm 0.6$ & $6.1 \pm 0.8$ & $21841 \pm 8667$ \\
\hline TPU-(PCL $\left.3-\mathrm{PEG}_{14}-\mathrm{PCL}_{3}\right)^{\mathrm{a}}$ & $70.2 / 29.8$ & soluble & - & - & - & - & - & - \\
\hline TPU-(PCL $\left.-\mathrm{PEG}_{10}-\mathrm{PCL}_{5}\right)$ & $49.8 / 50.2$ & 534 & $7 \pm 2$ & $4 \pm 1$ & $147 \pm 41$ & $3.0 \pm 0.6$ & $3.0 \pm 0.5$ & $513 \pm 267$ \\
\hline TPU-(PCL $\left.-\mathrm{PEG}_{6}-\mathrm{PCL}_{7}\right)$ & $29.5 / 70.5$ & 122 & $52 \pm 10$ & $17 \pm 2$ & $1553 \pm 155$ & $7.3 \pm 0.7$ & $13 \pm 2$ & $17976 \pm 3011$ \\
\hline
\end{tabular}


The toughness of the different TPU-(PCL-b-PEG- $b$-PCL) multi-block copolymers was also assessed in tearing experiments. Trouser tear propagation tests were performed in the dry- and in the wet-state, Table 5 gives an overview of the obtained results of the average tear propagation strength values, the maximum tear propagation strengths and the tearing energy. In the dry state TPUs TPU-(PCL $\left.-\mathrm{PEG}_{10}-\mathrm{PCL}_{5}\right)$ and TPU-(PCL $\left.-\mathrm{PEG}_{6}-\mathrm{PCL}_{7}\right)$ show comparable values of $\mathrm{TPS}_{\text {ave, }} \mathrm{TPS}_{\max }$ and $\mathrm{G}$. In the wet state, TPU-(PCL $\left.-\mathrm{PEG}_{10}-\mathrm{PCL}_{5}\right)$ is significantly less tough than in the dry state. Most interestingly, the high toughness of TPU-(PCL $\left.-\mathrm{PEG}_{6}-\mathrm{PCL}_{7}\right)$ is maintained in the hydrated state. It's important to note that both in the dry and in the wet state these TPU hydrogels compare very favorably to other hydrogel materials $[23,24]$. The tear propagation strengths and tearing energy of TPU-(PCL $\left.-\mathrm{PEG}_{14}-\mathrm{PCL}_{3}\right)$ could only be determined in the dry state, where its toughness was much lower than that of the other TPU-(PCL-b-PEG- $b$-PCL) multi-block copolymers.

Table 5. Tear propagation resistance of the different TPU-(PCL- $b$-PEG- $b$-PCL) polymers in the dry and in the wet state $(n=5$, average $\pm \mathrm{SD})$.

\begin{tabular}{|c|c|c|c|c|c|c|}
\hline & \multicolumn{2}{|c|}{ TPS $_{\text {ave }}(\mathrm{N} / \mathrm{mm})$} & \multicolumn{2}{|c|}{$\mathrm{TPS}_{\max }(\mathrm{N} / \mathrm{mm})$} & \multicolumn{2}{|c|}{$\mathrm{G}\left(\mathrm{kJ} / \mathrm{m}^{2}\right)$} \\
\hline & Dry & Wet & Dry & Wet & Dry & Wet \\
\hline TPU-(PCL $\left.3-\mathrm{PEG}_{14}-\mathrm{PCL}_{3}\right)$ & $44 \pm 12$ & $\mathrm{a}$ & $71 \pm 4$ & $\mathrm{a}$ & $89 \pm 12$ & $\mathrm{a}$ \\
\hline TPU-(PCL $\left.5-\mathrm{PEG}_{10}-\mathrm{PCL}_{5}\right)$ & $66 \pm 14$ & $8 \pm 2$ & $94 \pm 3$ & $13 \pm 4$ & $132 \pm 21$ & $16 \pm 4$ \\
\hline TPU-(PCL $\left.-\mathrm{PEG}_{6}-\mathrm{PCL}_{7}\right)$ & $64 \pm 18$ & $36 \pm 20$ & $93 \pm 13$ & $50 \pm 24$ & $127 \pm 31$ & $72 \pm 41$ \\
\hline
\end{tabular}

${ }^{\text {a }}$ Specimens take up large amounts of water and are very fragile.

\subsection{D Printing of TPU-(PCL-b-PEG-b-PCL) Multi-Block Copolymers}

Designed tissue engineering scaffolding structures were prepared by fused deposition modelling (FDM) of the TPU-(PCL $\left.-\mathrm{PEG}_{10}-\mathrm{PCL}_{5}\right)$ multi-block copolymer, as this thermoplastic hydrogel shows very high water uptake and excellent mechanical properties in the wet state. This TPU has a melting temperature of approximately $49^{\circ} \mathrm{C}$ and a decomposition temperature of approximately $400{ }^{\circ} \mathrm{C}$, as determined by thermogravimetric analysis (details not shown). To allow processing using a conventional commercially available FDM machine, filaments with a diameter of approximately $2.5 \mathrm{~mm}$ were first prepared by melt extrusion at $120^{\circ} \mathrm{C}$. The TPU filaments were then fed into the FDM apparatus to prepare the designed structures as described in the experimental part. The conditions were not thoroughly optimized, but an extrusion temperature of $180^{\circ} \mathrm{C}$, a nozzle diameter of $0.4 \mathrm{~mm}$ and a printing speed of $1 \mathrm{~mm} / \mathrm{s}$ were found to be well suited. The building platform was kept at a temperature near room temperature, as this is close to the maximum crystallization temperature (see Table 2). Figure 7a shows one of the 3D printed structures.

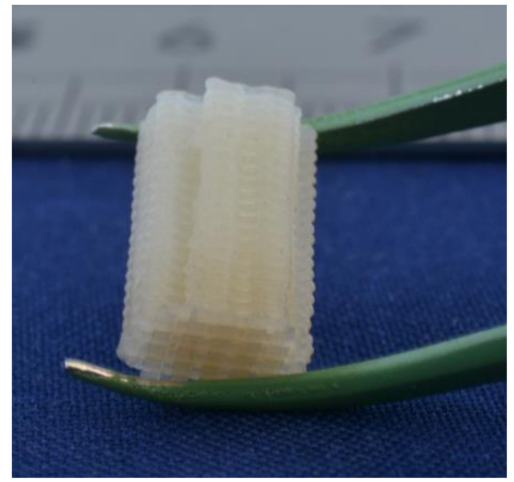

(a)

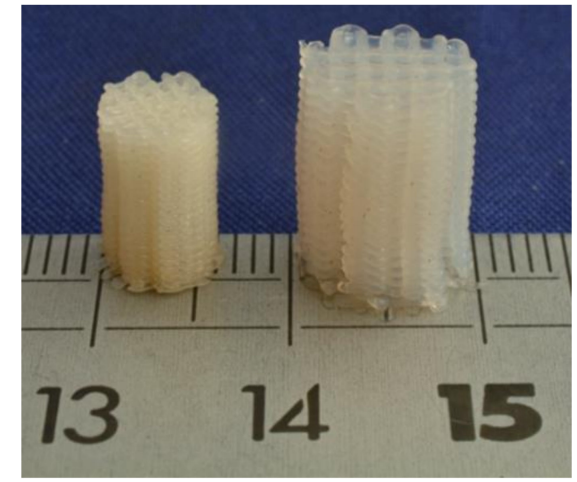

(b)

Figure 7. Designed structure prepared from TPU-(PCL $\left.-\mathrm{PEG}_{10}-\mathrm{PCL}_{5}\right)$ multi-block copolymer by fused deposition modelling: (a) Structure in the dry state and (b) comparison of the structure in the dry state and in the hydrated state. 
Figure $7 \mathrm{~b}$ compares the prepared structure in the dry state and in the wet state after taking up large amounts of water. The structure swells homogeneously in all directions, and features of the designed structure such as its geometry, struts and pores are enlarged upon hydration. While the 3D-printed structure is relatively rigid in the dry state, it is quite flexible and elastic in the hydrated state. After compression, it fully returns to its original shape.

TPU-(PCL- $b$-PEG- $b$-PCL) hydrogels are tough thermoplastic materials, consisting of hydrophilic PEG segments and hydrophobic PCL domains. Both components are crystallizable, but in the hydrated state it is the hydrophobic PCL domains that ensure the maintenance of the physical network. Figure 8 shows an overview of another $3 \mathrm{D}$ printed structure prepared from TPU-(PCL $\left.-\mathrm{PEG}_{10}-\mathrm{PCL}_{5}\right)$ in the dry state. In Figure 8a, an image of the overall structure is shown, where the fibers/strands have a width of approximately $200 \mu \mathrm{m}$ and the distance between the strands is close to $300 \mu \mathrm{m}$. Figure $8 \mathrm{~b}$ is a higher magnification of one of the strands. The higher magnifications of the SEM images in Figure 8c,d shows that the surface of the printed strands is not smooth, and that spherulitic crystalline structures with diameters of $5-7 \mu \mathrm{m}$ are present.

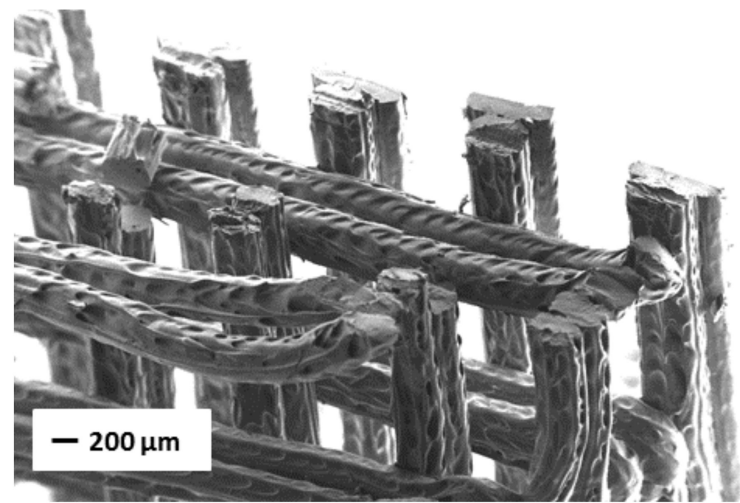

(a)

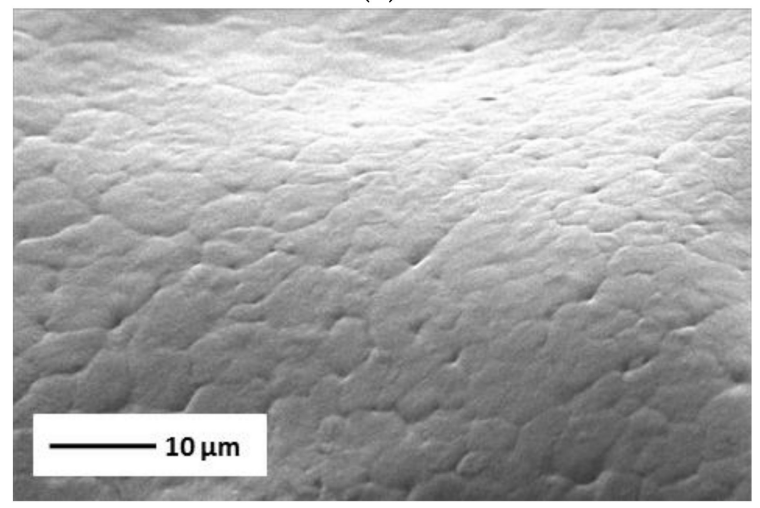

(c)

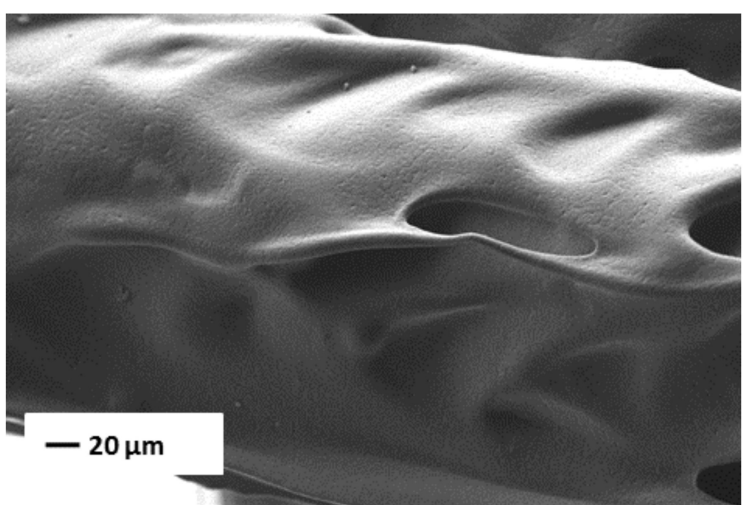

(b)

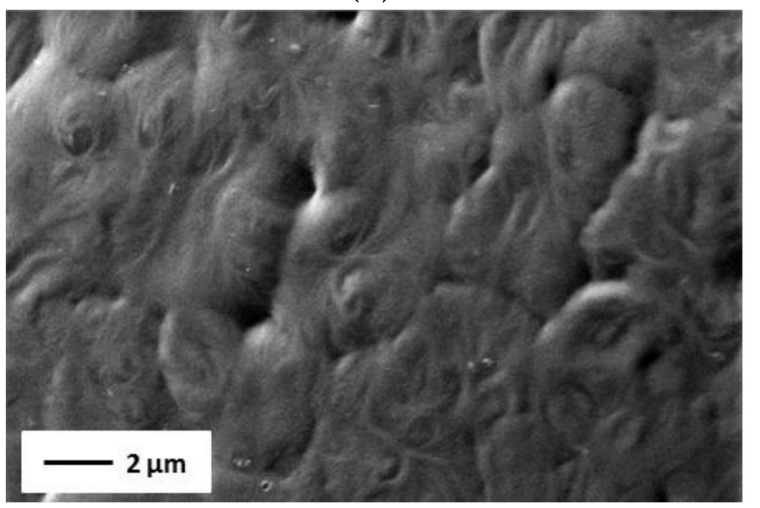

(d)

Figure 8. SEM images of 3D printed structures prepared from TPU-(PCL $\left.-\mathrm{PEG}_{10}-\mathrm{PCL}_{5}\right)$ in the dry state at different magnifications. (a) overview of a printed structure, $(\mathbf{b}-\mathbf{d})$ images of the surface of the printed structure at higher magnifications.

\section{Conclusions}

Thermoplastic polyurethanes based on PCL- $b$-PEG- $b$-PCL triblock copolymers can be prepared by a reaction of the triblock copolymers with hexamethylene diisocyanate. Depending on their PEG content, the synthesized TPU-(PCL- $b$-PEG- $b$-PCL) materials can take up large amounts of water of more than $500 \%$. This allows them to be used as biodegradable thermoplastic hydrogels. Furthermore, these materials were shown to have excellent mechanical properties displaying high tensile strength, elongation at break, toughness and tear resistance in the dry as well as in the highly water-swollen state. This work has shown that these advanced thermoplastic materials can readily be processed 
into designed hydrogel structures by fused deposition modelling using conventional equipment, thus allowing them to be used in a variety of biomedical applications. Future work will address optimization of the printing process and the properties of built structures in more detail.

Author Contributions: A.G., C.G. and A.M. designed the study, carried out the experimental work and drafted the manuscript. D.W.G. and J.M. arranged funding, designed the experiments, supervised the research work and corrected the manuscript.

Funding: This research was supported by Stichting Bevordering Biomaterialen and the Erasmus Mundus program of the European Union.

Conflicts of Interest: The authors declare no conflicts of interest.

\section{References}

1. Bae, J.; Bende, N.P.; Evans, A.A.; Na, J.H.; Santangelo, C.D.; Hayward, R.C. Programmable and reversible assembly of soft capillary multipoles. Mater. Horizons. 2017, 4, 228-235. [CrossRef]

2. Yuk, H.; Zhang, T.; Parada, G.A.; Liu, X.; Zhao, X. Skin-inspired hydrogel-elastomer hybrids with robust interfaces and functional microstructures. Nat. Commun. 2016, 7, 1-11. [CrossRef] [PubMed]

3. Fung, Y.C. Biomechanics. In Mechanical Properties of Living Tissues, 2nd ed.; Springer: New York, NY, USA, 1993.

4. Dissanayaka, W.L.; Hargreaves, K.M.; Jin, L.; Samaranayake, L.P.; Zhang, C. The interplay of dental pulp stem cells and endothelial cells in an injectable peptide hydrogel on angiogenesis and pulp regeneration in vivo. Tissue Eng. A 2015, 21, 550-563. [CrossRef] [PubMed]

5. Koutsopoulos, S. Self-assembling peptide nanofiber hydrogels in tissue engineering and regenerative medicine: Progress, design guidelines, and applications. J. Biomed. Mater. Res. A 2016, 104, 1002-1016. [CrossRef] [PubMed]

6. Kamata, H.; Akagi, Y.; Kayasuga-kariya, Y.; Chung, U.; Sakai, T. Nonswellable hydrogel without mechanical hysteresis. Science 2014, 343, 873-875. [CrossRef] [PubMed]

7. Zant, E.; Grijpma, D.W. Tough biodegradable mixed-macromer networks and hydrogels by photo-crosslinking in solution. Acta Biomater. 2016, 31, 80-88. [CrossRef] [PubMed]

8. Zant, E.; Grijpma, D.W. Synthetic biodegradable hydrogels with excellent mechanical properties and good cell adhesion characteristics obtained by the combinatorial synthesis of photo-cross-linked networks. Biomacromolecules 2016, 17, 1582-1592. [CrossRef] [PubMed]

9. Sun, T.L.; Kurokawa, T.; Kuroda, S.; Bin Ihsan, A.; Akasaki, T.; Sato, K.; Haque, M.A.; Nakajima, T.; Gong, J.P. Physical hydrogels composed of polyampholytes demonstrate high toughness and viscoelasticity. Nat. Mater. 2013, 12, 932-937. [CrossRef] [PubMed]

10. Costa, A.M.S.; Mano, J.F. Extremely strong and tough hydrogels as prospective candidates for tissue repair-A review. Eur. Polym. J. 2015, 72, 344-364. [CrossRef]

11. Ni, Y.; Tang, Z.; Cao, W.; Lin, H.; Fan, Y.; Guo, L; Zhang, X. Tough and elastic hydrogel of hyaluronic acid and chondroitin sulfate as potential cell scaffold materials. Int. J. Biol. Macromol. 2015, 74, 367-375. [CrossRef] [PubMed]

12. Malda, J.; Visser, J.; Melchels, F.P.; Jüngst, T.; Hennink, W.E.; Dhert, W.J.A.; Groll, J.; Hutmacher, D.W. 25th anniversary article: Engineering hydrogels for biofabrication. Adv. Mater. 2013, 25, 5011-5028. [CrossRef] [PubMed]

13. Mouser, V.H.M.; Levato, R.; Bonassar, L.J.; D’Lima, D.D.; Grande, D.A.; Klein, T.J.; Saris, D.B.F.; Zenobi-Wong, M.; Gawlitta, D.; Malda, J. Three-dimensional bioprinting and its potential in the field of articular cartilage regeneration. Cartilage 2017, 8, 327-340. [CrossRef] [PubMed]

14. Kirchmajer, D.M.; Gorkin, R., III. An overview of the suitability of hydrogel-forming polymers for extrusion-based 3D-printing. J. Mater. Chem. B 2015, 3, 4105-4117. [CrossRef]

15. Shelke, N.B.; Nagarale, R.K.; Kumbar, S.G. Polyurethanes. In Natural and Synthetic Biomedical Polymers, 1st ed.; Kumbar, S.G., Laurencin, C., Deng, M., Eds.; Elsevier: Amsterdam, The Netherlands, 2014; pp. 123-144.

16. Wu, F.; Chen, L.; Li, Y.; Lee, K.I.; Fei, B. Super-tough hydrogels from shape-memory polyurethane with wide-adjustable mechanical properties. J. Mater. Sci. 2017, 52, 4421-4434. [CrossRef]

17. Jen, A.C.; Wake, M.C.; Mikos, A.G. Hydrogels for cell immobilization. Biotechnol. Bioeng. 1996, 50, 357-364. [CrossRef] 
18. Lendlein, A.; Langer, R. Biodegradable, elastic shape-memory polymers for potential biomedical applications. Science 2002, 296, 1673-1676. [CrossRef] [PubMed]

19. Yen, M.S.; Kuo, S.C. PCL-PEG-PCL Triblock Ester-Ether Copolydiol-Based Waterborne Polyurethane. II. Effect of NCO/OH Mole Ratio and DMPA Content on the Physical Properties. J. Appl. Polym. Sci. 1998, 67, 1301-1311. [CrossRef]

20. Yen, M.S.; Kuo, S.C. Effects of a soft segment component on the physical properties of synthesized waterborne polyurethanes by using triblock ester-ether copolydiol as the soft segment. J. Polym. Res. 1998, 5, 125-131. [CrossRef]

21. Dušek, K.; Ilavský, M.; Matějka, L. Statistical treatment of allophanate crosslinking in the formation of polyurethane networks. Polym. Bull. 1984, 12, 33-40. [CrossRef]

22. Hoo Fatt, M.S.; Chen, L.; Al-Quraishi, A.A. Fracture parameters for natural rubber under dynamic loading. Strain 2011, 47, 505-518. [CrossRef]

23. Tonsomboon, K.; Butcher, A.L.; Oyen, M.L. Strong and tough nanofibrous hydrogel composites based on biomimetic principles. Mater. Sci. Eng. C 2017, 72, 220-227. [CrossRef] [PubMed]

24. Naficy, S.; Brown, H.R.; Razal, J.M.; Spinks, G.M.; Whitten, P.G. Progress toward robust polymer hydrogels. Aust. J. Chem. 2011, 64, 1007-1025. [CrossRef]

(C) 2018 by the authors. Licensee MDPI, Basel, Switzerland. This article is an open access article distributed under the terms and conditions of the Creative Commons Attribution (CC BY) license (http:/ / creativecommons.org/licenses/by/4.0/). 